\title{
Study on industry chain financing mode of small and medium enterprises
}

\author{
Mengyao Li \\ Economics and Management School, Wuhan University, Wuhan, 430072, China
}

Keywords: small and medium enterprises; industry chain; financing

\begin{abstract}
Industry chain financing is a new choice to effectively solve the difficulty in financing by Chinese small and medium enterprises. Since industry chain financing focuses on industry chain to implement various financial services, small and medium enterprises in the upstream and downstream of the industry chain can gain active credit support of commercial banks so that they can well relieve financing difficulty. This paper expounds the necessity of developing industry chain financing for small and medium enterprises and unique advantage of industry chain financing, lists outstanding problems of industry chain financing and proposes suggestions to perfect industry chain financing mode of small and medium enterprises on the basis of defining relevant concepts.
\end{abstract}

\section{Introduction}

Currently, the number of Chinese small and medium enterprises accounts for more than 95\% of the total number of enterprises, while the output value exceeds $60 \%$ and the tax revenue exceeds $43 \%$. It thus can be seen that small and medium enterprises play a very important role in national economic system and industry chain activities. In the era of post-financial crisis, most small and medium enterprises in China have such problems as capital shortage and financing difficulty. Many enterprises go bankrupt. To effectively break through financing difficulty of Chinese small and medium enterprises and expand existing financing approaches, relevant experts propose new financing mode called industry chain financing according to relevant researches on industry chain theories and in combination of features of small and medium enterprises. The largest feature of industry chain financing is that credit linkage is conducted for core enterprises in the industry chain as well as small and medium enterprises in the chain. Financing problem and supply chain imbalance problem are solved through injecting funds into matched small and medium enterprises in the upstream and downstream in the weak position. Meanwhile, bank credit is penetrated into buying and selling behaviors of small and medium enterprises in the upstream and downstream to help small and medium enterprises as well as the core enterprises to form long-term strategic cooperation relationship, practically boost the ability of the enterprises in the cluster to resist risks and improve market competitiveness of the industry chain.

\section{Definition of relevant concepts}

1) Industry chain. Industry chain refers to the set of numerous relevant activities to create value. These activities are distributed in each link from acquisition of raw materials from suppliers to product consumption. Each link is correlated and interacts. The industry chain is bound by the value. Large-scale key enterprises are in the core position. The small and medium enterprises surviving by depending on large enterprises can certainly share the value. For various financial services developed for small and medium enterprises, once they can focus on this clue, the customer base of financial service will naturally have clear clue. Meanwhile, there is very high income and very low risk. 2) Industry chain financing. Industry chain financing means commercial banks connect core enterprises with upstream and downstream enterprises through expanding services of core enterprises, from raw material purchase, intermediate products, finished products to delivery of the products to consumers through sales network. The chain of the industry chain connects supply enterprises, manufacturing enterprises, distribution enterprises, retail enterprises and even all users to an entirety and provides financing services for numerous enterprises in the industry chain. 
Besides, continuous appreciation of the whole industry chain is realized through functional division and cooperation of relevant enterprises.

\section{Necessity of developing industry chain financing for small and medium enterprises}

To properly solve financing problem of Chinese small and medium enterprises, China always actively encourages commercial banks to be oriented to small and medium enterprises to implement financial innovation. It is required to actively improve credit rating mechanism implemented for small and medium enterprises according to distinct characteristics of small and medium enterprises. For the small and medium enterprises complying with relevant conditions, corresponding credit loans should be granted for them. Credit extension service should be provided. For the small and medium enterprises with market, benefit and credit, it is necessary to actively expand enterprise finance and account custody business, and fully encourage insurance enterprises to aim at product and service innovation of small and medium enterprises so as to improve service modes and means of small and medium enterprises. Local commercial financial network should be applied to implement sub-loan business for small and medium enterprises. Besides, re-guarantee should be available for the small and medium enterprises with corresponding conditions so as to actively guide financial institutions to implement financial innovation and improve financial services.

Financial institutions provide services for each enterprise in the industry chain. The supply enterprises in the upstream and sales enterprises in the downstream are mainly small and medium enterprises. Since these enterprises have small scale and it is hard to solve physical security and pledge, it is very difficult to find out suitable financing approaches. Thus, industry chain is breaks due to fund shortage, and small and medium enterprises lose excellent market development opportunities. The core enterprises have to seek new cooperation companies externally. So, the cost increases. Therefore, if industry chain operation can be directly influenced and if numerous enterprises in the industry chain can be regarded as a complete entirety, upstream and downstream small and medium enterprises of core enterprises in the industrial cluster are expanded actively by focusing on capital chain of core enterprises in industrial cluster to form business chain and risk control chain, financing problem of Chinese small and medium enterprises can be well solved and meanwhile industry chain can gain new development.

Industry chain financing service can make small land medium enterprises enter credit system. Previously, commercial banks were unwilling to provide loans for vast small and medium enterprises. This is mainly because the operation of small land medium enterprises is very scattered. Thus, the repayment risk increases. The movable properties used for pledging are relatively few. Credit rating of small land medium enterprises is quite low. So, the transaction cost and risk of commercial financial institutions increases. Therefore, commercial banks are only willing to lend money to large enterprises which will bring them with high return rate. Industry chain financing can allow small land medium enterprises to enter the view of commercial financial institutions through evaluating overall industry chain and the exchange. Meanwhile, industry chain financing can well mobilize commercial banks to research and develop more new financial products to improve operation initiative and flexibility as well as profit space of commercial financial institutions. Industry chain financing can break through traditional loan mode. The service is not oriented to producers, manufacturers, sellers and other independent enterprises in the industry chain in the market any more. Thus, large core enterprises should be found out in the supply chain to provide larger financial support for industry chain. The capital can be injected in upstream and downstream small and medium enterprises in the weak position. Besides, financing problem can be well solved for small and medium enterprises. Credit of commercial banks can also be penetrated in buying and selling behaviors of upstream and downstream enterprises to improve commercial credit and boost competitiveness of the supply chain.

\section{Unique advantages of industry chain financing}

1) Improve the value of industry chain. The author considers " $1+N$ " service mode can change 
traditional credit extension mode of commercial bank dominated by single enterprises. It focuses on a core enterprise and provides corresponding financing services for numerous enterprises in the industry chain so that long-term and stable strategic cooperation relationship can be established between small \& medium enterprises and core enterprises. Besides, continuous appreciation of the whole industry chain is realized through functional division and cooperation of relevant enterprises. 2) Improve enterprises' business reputation. Binding credit of core enterprises and small \& medium enterprises can greatly improve commercial credit of small and medium enterprises. Core enterprises can apply industry chain to closely connect production link and circulation link. This mode can effectively solve financing problems of small and medium enterprises. Meanwhile, it can promote interactions between finance and the industry and boost core enterprises to gain the information about the demand of products and services. 3) Control bank risks. Industry chain can not just solve lending risks of commercial banks. When commercial banks consider operation status of small and medium enterprises, they should deeply investigate the operation status, logistics situation and capital control situation of core enterprises in the industry chain. After comprehensive evaluation is implemented, the mode ideal financing mode can be set for small and medium enterprises to reduce lending risks and gain higher income. Meanwhile, commercial banks can solve the risk of remote financial business. Various commercial financial institutions have numerous remote businesses, but it is extremely to control remote financial risks. During industrial chain financing operation, since remote enterprises have correlated enterprises, corresponding risks can be controlled from information perspective. 4) Effectively control capital flow. Since commercial banks focus on core enterprises for financing, the financing plan designed by commercial banks should be able to effectively control loan fund flow. Trade acceptance and enterprise inventory should be applied to make the funds injected in supporting enterprises of the industry chain more rationally and then improve the operating ability of the weak link in the industry chain.

\section{Outstanding problems in industry chain financing of small and medium enterprises}

1) In industry chain financing, banks and enterprises have debit and credit contradictions. Commercial banks, small and medium enterprises have debit and credit contradictions. On the one hand, compared with large enterprises, it is hard for small and medium enterprises to provide qualified financial statements. Thus, commercial banks do not grasp much information on financial condition, product sales thought and market prospect of small and medium enterprises. In this way, information asymmetry between small \& medium enterprises and commercial banks will increase. At the same time, some small and medium enterprises have poor credit, so commercial banks prefer to granting loans to large enterprises and neglect the loans issued to small and medium enterprises.

2) In industry chain financing, the contradictions exist between core enterprises and other small \& medium enterprises. The main contradiction between core enterprises and other small \& medium enterprises is interest imbalance. On the one hand, core enterprises lower purchasing price as far as possible in the whole industry chain in order to gain higher economic benefit. Thus, the profit space of small and medium enterprises becomes increasingly small, thus leading to inertest loss. On the other hand, since the scale of small and medium enterprises is relatively small, they cannot meet the need of development of core enterprises. Core enterprises may select other enterprises again in the industry chain in order to satisfy the development need. 3) In industry chain financing, small and medium enterprises have contradictions. Upstream enterprises and downstream enterprises have contradictions. In the industry chain, small and medium enterprises in the upstream may increase the selling price as far as possible, while the purchasing price of small and medium enterprises in the downstream may rise so that the profit rate drops. If the transaction in o link in the industry chain is not realized, it is hard to realize the while industry chain transaction. Thus, the economy is affected.

\section{Suggestions on perfecting industry chain financing mode of small and medium enterprises}

Firstly, it is required to accelerate development pace of Chinese small and medium enterprises. 
More effective modern enterprise administration must be established and perfected to improve comprehensive management ability of Chinese small and medium enterprises, establish good brand awareness and comprehensively implement brand development strategy. Meanwhile, it is required to continuously enhance enterprise information-based construction and boost rapid response ability of small and medium enterprises for modern market. Secondly, it is required to perfect core competitiveness system of enterprises and boost industry chain value of enterprises. In the industry chain of small and medium enterprises, core enterprises are generally integrated through industry chain management. Thus, unique management financing mode different from other industry chains forms. Then, distinct core market competitiveness based on industry chain forms to improve industry chain value. Thirdly, justice and trust relationship should be established among different enterprises. Core enterprises in the industry chain should be devoted to constructing more fair management system do that the enterprises in the industry chain can give up short-term benefit maximization and obey long-term benefit maximization of the industry chain. Then, win-win situation can be achieved for small land medium enterprises in the industry chain. Fourthly, strategic alliance form should be applied to enhance mutual cooperation among various enterprises. To establish hand perfect strategic alliance, it is required to change the idea fundamentally and make cooperation parties achieve the consensus of strategic cooperation and establish good industry chain cooperation relationship. Fifthly, credit mechanism, responsibility mechanism and supervision mechanism should be established and perfected. Credit industry association as a self-regulation organization is mainly composed of small land medium enterprises in different industries. It has quite high requirements for credit degree of member enterprises. All members can supervise each other and then improve the credit degree. To perfect industry chain financing mode, more perfect responsibility system must be established. The corresponding duties of each enterprise in each kink should be specified to prevent enterprises from violating the contract and protect vital interest of various enterprises in other industry chains. Core enterprises are leading enterprises in the industry chain and should actively perform supervision obligation to reduce asset loss risk in transactions and make the industry chain become more stable and reliable.

\section{Conclusions}

Generally speaking, competitions among enterprises have evolved to competitions among industry chains. As long as credit binging is conducted for core enterprises, upstream and downstream suppliers and retailers as a whole and financing services are implemented overall, financing problem can be solved for the industry chain; overall competitiveness of competitiveness can improve; great development of financial institutions can be promoted; all-win and sustainable development of local economy can be realized.

\section{References}

[1] Dou Bin, Study on development strategy of China auto financing companies based on industry chain [J]. Auto Industry Research, 2013 (3)

[2] Chen Xi, Study in integration of China fashion industry chain in post-financial crisis period [J]. Foreign Trade, 2012 (11)

[3] Zhang Jindong, Industry chain finance: effective mode to cope with "three difficulties" of micro-finance [J]. Finance in Zhejiang, 2013 (4)

[4] Chang Jiancong, Exploration of derivative industry chain financing innovation path of great projects of Yangtze River Delta [J]. Contemporary Economy, 2013 (8)

[5] Wang Guoxin, Exploration of industry chain financing service mode based on financial companies [J]. Commercial Accounting, 2013 (10) 